\title{
Prosedur Production Control Pada Pt Astra Honda Motor Jakarta
}

\author{
Maya Sofiana \\ Institut Ilmu Sosial dan Manajemen Stiami \\ Email : msofiana@yahoo.com
}

\section{ARTICLE INFO}

Keywords

Occupational Safety and

Health (OHS), Management

\section{ABSTRACT}

This writing aims to know how to procedures of production control on PT Astra Honda Motor (PT AHM) on Jakarta. This writing is executed on PT AHM, with the methods of literature writing, observation, and interviews. The results of this writing is represent that, procedures of production control is still not suitable because it is still in development stage, so less than the maximum in the application of production planning, production control, and production actual. The procedures of production control on PT AHM Jakarta of production planning, production control, and production actual. The constraints faced is the procedures of production control on PT AHM Jakarta is difficult to implement prosedures for changing the order of planning on the day running, SFG lacks parts, there are parties who disagree about the minus burden. The solutions in facing is the procedures of production control on PT AHM Jakarta is in the case of production planning, in case of force, a change in order is permitted provided all parts are available, in the case of control production, in case of important. In the case control production, SFG is allowed as long as it can be completed that day. In the case actual production, disputing parties are accommodated, meetings with related parties.

\section{PENDAHULUAN}

Persaingan industri otomotif yang ada di Indonesia belakangan ini sangatlah kuat, yang mana semua merk industri otomotif tidak terkecuali sepeda motor dituntut untuk menciptakan sepeda motor yang berkualitas tinggi, nyaman dikendarai, hemat bahan bakar, dan harga yang terjangkau disemua kalangan masyarakat karena sepeda motor saat ini sudah menjadi kebutuhan masyarakat untuk beraktivitas sehari-hari, ini tercermin dari evens motor show yang selalu padat dikunjungi oleh masyarakat, seperti Indonesia Motorcycle Show (IMOS) 2014 Jakarta. Penjualan sepeda motor merk Honda melampaui target penjualan yang telah ditetapkan. Pencapaian penjualan AHM (Astra Honda Motor) ini mencerminkan tingginya animo masyarakat untuk memiliki sepeda motor Honda.

Menurut data dari PT Astra International Tbk., yang dilansir dari Asosiasi Industri Sepeda Motor Indonesia (AISI), penjualan Honda di Pebruari lalu sebanyak 376.973 unit atau meningkat sebanyak 10,92 persen dibandingkan dengan Januari 2015 yang mencatatkan penjualan sebanyak 339.850 unit. Secara kumulatif penjualan sepeda motor Honda di Januari-Pebruari tahun ini tercatat sebanyak 716.823 unit. Honda berhasil menguasai pangsa pasar sebesar 68 persen dari total pasar sepeda motor nasional di dua bulan pertama 2015 sebanyak 1.058 .874 unit.

Untuk dapat terciptanya eksistensi perusahaan dalam menguasai pangsa pasar perlu dikedepankan pentingnya mutu produk, hal ini tidak terlepas dari fungsi pengawasan yang merupakan salah satu fungsi manajemen. Seperti diketahui bahwa fungsi pengawasan terkadang tidak mendapat tempat utama dalam suatu orgasinisasi, suatu permasalahan besar terjadi barulah fungsi pengawasan dilakukan dengan optimal. Seyogyanya fungsi pengawasan itu dilaksanakan secara bersamaan dengan fungsi perencanaan, karena fungsi pengawasan itu dimulai sejak awal perencanaan. Oleh karena itu fungsi pengawasan khususnya dalam hal ini pengawasan produk sangatlah penting. 
Berdasarkan pengamatan di bagian Production Control yang bertugas mengatur dan menyesuaikan rencana produksi dengan kenyataan (actual) yang terjadi agar rencana produksi bisa dipenuhi sesuai dengan quantity, type and color permintaan Marketing di setiap periodenya, masih terjadi adanya keterlambatan.

Berdasarkan latar belakang masalah di atas penulis tertarik untuk mengambil judul dalam penulisan karya tulis ilmiah ini dengan judul "Prosedur Production Control pada PT ASTRA HONDA MOTOR JAKARTA". Yang menjadi pokok masalah di sini adalah bagaimana "Prosedur Production Control pada PT Astra HONDA MOTOR JAKARTA".

Hasil penelitian ini diharapkan dapat dijadikan bahan pengembangan konsep pengawasan produksi sehingga menjadi masukan dalam pengambilan keputusan di bidang fungsi pengawasan khususnya pengawasan produksi oleh perusahaan dan dapat dijadikan dokumen ilmiah untuk pengembangan ilmu manajemen. Bagi pemerintah juga agar pemerintah dapat menjalankan perannya dalam mendukung iklim yang kondusif dalam kesempatan berusaha bagi swasta.

\section{Metodologi Penulisan}

Dalam pembuatan tulisan ini, penulis membutuhkan data-data yang berhubungan dengan kajian penulis, yaitu bersumber dari:

\section{Studi Pustaka (Library Research) \\ Yaitu pengumpulan data-data dengan cara mempelajari berbagai bentuk bahan-bahan tertulis seperti buku-buku penunjang kajian, Koran, dan catatan-catatan maupun referensi lain yang bersifat tertulis.}

\section{Studi Lapangan (Field Research)}

Yaitu penelitian dengan cara mendatangi langsung ke perusahaan yang menjadi objek kajian. Teknik pengumpulan datanya, yaitu wawancara dan observasi.

\section{KAJIAN LITERATUR}

\section{Pelaksanaan}

Departemen Pendidikan Nasional (2014:774) definisi pelaksanaan adalah sebagai berikut: "proses, cara, perbuatan melaksanakan (rancangan, keputusan, dan sebagainya)". melaksanakan".

Lalu Hizair (2013:350) mendefinisikan pelaksanaan sebagai berikut: "proses dan cara

\section{Prosedur}

Prosedur dalam Kamus Lengkap Bahasa Indonesia penyusun Virgirama \& Sulthon (2013:330) yaitu: Cara kerja, cara manjalankan dan Suemohadiwidjojo (2014:11) mengungkapkan: "Prosedur adalah merupakan salah satu jenis dokumen dalam sebuah system tata kerja yan diunakan untuk mengatur kegiatan operasional antar bagian/fungsi dalam sebuah organisasi, agar kegiatan tersebut dapat berjalan secara sistemik". Demikian pula menurut menurut penulis lain "Prosedur yaitu langkah-langkah atau tahapan yang berhubungan dengan proses dalam aktivitas kerja". Purnamasari (2015:11)

\section{Manfaat prosedur}

Manfaat prosedur menurut Purnamasari (2015:12) adalah untuk memudahkan akses informasi dan ketentuan yang dimaksud. Sedangkan menurut Santoso (2014:17) prosedur memiliki manfaat yaitu:

1. Menyediakan sebuah rekaman aktivitas, juga pengoperasian secara praktis

2. Menyediakan sebuah informasi yang konsisten, oleh karenanya juga membentuk disiplin kepada semua anggota organisasi baik dalam institusi, organisasi, maupun perusahaan.

3. Memudahkan menyaring, menganalisis, dan membuang hal-hal atau pekerjaan yang tidak perlu, yang tidak berkaitan secara langsung dengan prosedur yang sudah ada.

4. Mendukung pengalaman dan pengetahuan pegawai, dan sekaligus juga mengantisipasi banyak kesalahan yang mungkin terjadi.

5. Memperbaiki perporma, atau kualitas pegawwai itu sendiri.

6. Membantu menguatkan regulasi perusahaan.

7. Memastikan efisiensi tiap-tiap aktivitas operasional.

8. Menjelaskan segala peralatan untuk keefektifan program pelatihan. 


\section{Prinsip-prinsip Prosedur}

Uman (2014:152) pada hakikatnya, "prosedur kerja disusun agar setiap kekerjaan dapat diselesaikan menurut limit waktu yang ditentukan". Untuk menyusun prosedur diperlukan proses yang panjang dan dilakukan oleh orang yang berkompeten di bidangnya. Penyusunan prosedur kerja harus berdasarkan prinsipprinsip berikut:

1. Rasional: setiap prosedur kerja harus masuk akal dan mudah dipahami sehingga pekerjaan setiap orang sesuai dengan klasifikasinya agar mudah untuk dimengerti.

2. Sistematis: menggunakan urutan kerja yang teratur, yakni mengalir dari tahap pertama sampai tahap selanjutnya.

3. Bersifat operasional: menjelaskan teknis pelaksanaan yang dapat dikerjakan dan dapat bersifat teoritis.

4. Menggunakan jarak terpendek: setiap pekerjaan sedapat mungkin tidak melalui jalur atau jenjang yang panjang.

5. Menekankan pada prisip kerja: semua pekerjaan yang seling berkaitan ditempatkan secara berurutan.

\section{Production/Produksi}

Dalam Kamus Lengkap Bahasa Indonesia produksi adalah : Hasil, penghasilan barang-barang yang dibuat atau dihasilkan. Sedangkan Menurut Fahmi (2014:2) Produksi adalah: "Sesuatu yang dihasilkan oleh suatu perusahaan baik berbentuk barang (goods) maupun jasa (service) dalam suatu periode waktu yang selanjutnya dihitung sebagai nilai tambah bagi perusahaan".

Jika ditelaah lebih lanjut pengertian Produksi dapat di tinjau dari 2 (dua) sudut, yaitu:

1. Pengertian produksi dalam arti sempit, yaitu mengubah bentuk barang menjadi barang baru, ini menimbulkan form utility.

2. Pengertian produksi dalam arti luas, yaitu usaha yang menimbulkan kegunaan karena place, time, dan possession.

\section{Manfaat Produksi}

Menurut Murdifin \& Mahfud (2011:3) "produksi berfungsi untuk menciptakan kegunaan bentuk (form utility), karena melalui kegiatan produksi nilai dan kegunaan suatu benda meningkat akibat dilakukannya penyempurnaan bentuk atas benda (input)".

\section{Control (kontrol)}

Dalam Kamus Lengkap Bahasa Indonesia penyusun Tri Nurhayati (2012:397) arti Kontrol adalah "pengawasan, pemeriksaan". Kontrol menurut Hery (2014:9) adalah "sebuah proses yang menjamin bahwa tugas tertentu telah dilakukan secara efektif dan efisien". yaitu:

Berpendapat Hery (2014:1) setiap sistem control sekurang-kurangnya memiliki 4 (empat) elemen

1. Detektor (sensor) yakni alat yang menukur apa yang nyata-nyata sedang terjadi dalam proses yang sedang dikendalikan.

2. Asesor yakni alat yang menentukan signifikasi dari apa yang nyata-nyata sedang terjadi melalui perbandingan dengan beberapa standar atau ekspektasi dari apa yang seharusnya terjadi.

3. Efektor yakni alat (umpan balik) yang akan mengubah perilaku jika asesor menunjukan kebutuhan untuk melakukannya.'

4. Jaringan komunikasi yakni alat yang akan meneruskan informasi dari detector ke asesor dan dari asesor ke efektor

\section{Manfaat Kontrol}

Manfaat Kontrol yaitu untuk membandingkan antara rencana awal dan hasil actual, dan apabila ada kesalahan dalam proses, pekerjaan bisa langsung terdeteksi sumber masalahnya.

Menurut Khairani (2013:1) Production Control adalah :

"Suatu kegiatan yang disusun sesuai dengan kemampuan sumber-sumber yang digunakan dalam memenuhi rencana produksi, kemampuan produksi yang sedang berjalan dan melakukan perbaikan rencana, dimana fungsi kegiatan dalam pengendalian produksi mengarahkan atau mengatur pergerakan material termaksud di dalamnya bahan, komponen dan produk melalui suatu siklus manufaktur, mulai dari permintaan bahan baku sampai dengan pengiriman produk akhir kepada pelanggan". 


\section{Prosedur Production Control}

Prosedur production control adalah urutan kerja yang diatur oleh perusahaan dalam melakukan kontrol agar meyakinkan planning produksi dapat sesuai dengan perencanaan.

\section{METODE PENELITIAN}

Dalam pembuatan tulisan karya ilimiah ini, penulis membutuhkan data-data yang berhubungan dengan kajian penulis, yaitu bersumber dari:

\section{Studi Pustaka (Library Research)}

Yaitu pengumpulan data-data dengan cara mempelajari berbagai bentuk bahan-bahan tertulis seperti buku-buku penunjang kajian, Koran, dan catatan-catatan maupun referensi lain yang bersifat tertulis.

\section{Studi Lapangan (Field Research)}

Yaitu penelitian dengan cara mendatangi langsung ke perusahaan yang menjadi objek kajian. Teknik pengumpulan datanya, yaitu wawancara dan observasi.

\section{HASIL DAN PEMBAHASAN}

\section{Prosedur Production Control Pada PT Astra Honda Motor}

Dalam melakukan kontrol, banyak hal yang harus kita perhatikan, seluruh aktivitas dan perhatian kita mengarah kepada pencapaian produksi secara kuantitas sesuai planning yang diharapkan. Format pengontrolan yang benar dan konsistensi terhadap sistem kontrol merupakan hal utama dalam mengontrol produksi. Pada Bab ini penulis akan membahas apa dan bagaimana Production Control bisa berjalan sehingga tujuan production control mencapai produksi harian sesuai planning MPS bisa dijalankan dengan baik.

Hal pertama yang harus dimengerti dalam melakukan kontrol adalah apa yang harus dikontrol. Dibawah ini adalah Flowchard Production Control Pada PT Astra Honda Motor.

\section{Gambar 4.1}

Flowchart Prosedur Production Control

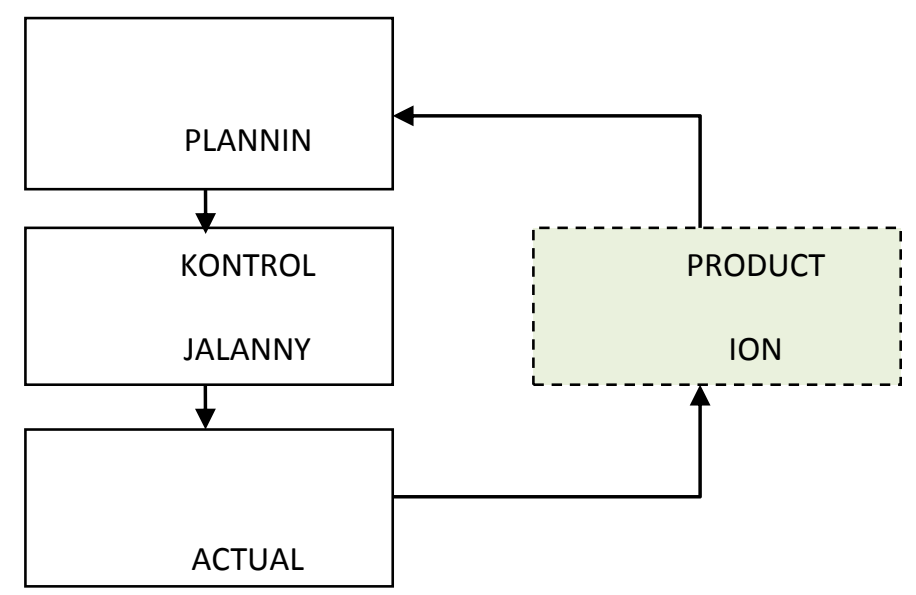

Sumber: PT Astra Honda Motor

Setelah melihat gambar 4.1 di atas, bahwa $P C$ memiliki fungsi utama sebagai pengontrol pencapaian produksi agar sesuai dengan MPS. Karena itu yang harus dikontrol PC adalah pencapaian produksi, namun tidak hanya itu, PC juga harus mampu menyusun strategi agar jumlah produksi sesuai dengan MPS. Berikut ini penulis menjelaskan mengenai Flowchard Prosedur Production Control Pada PT Astra Honda Motor:

\section{Planning Produksi (MPS \& Planning 3 Harian)}

Seperti yang tertera di Gambar 4.1 Production Planning memberikan planning 3 harian kepada Production Control. PC akan memberikan feedback kepada Production Planning jika Planning 3 Harian dianggap kurang memungkinkan untuk dicapai karena ada seksi atau sub contractor yang mengalami 
masalah dalam proses produksinya, atau masalah lain yang mengakibatkan Planning 3 Harian tidak mungkin untuk dicapai.

Gambar 4.2

Planning Yang Sesuai Just In Time

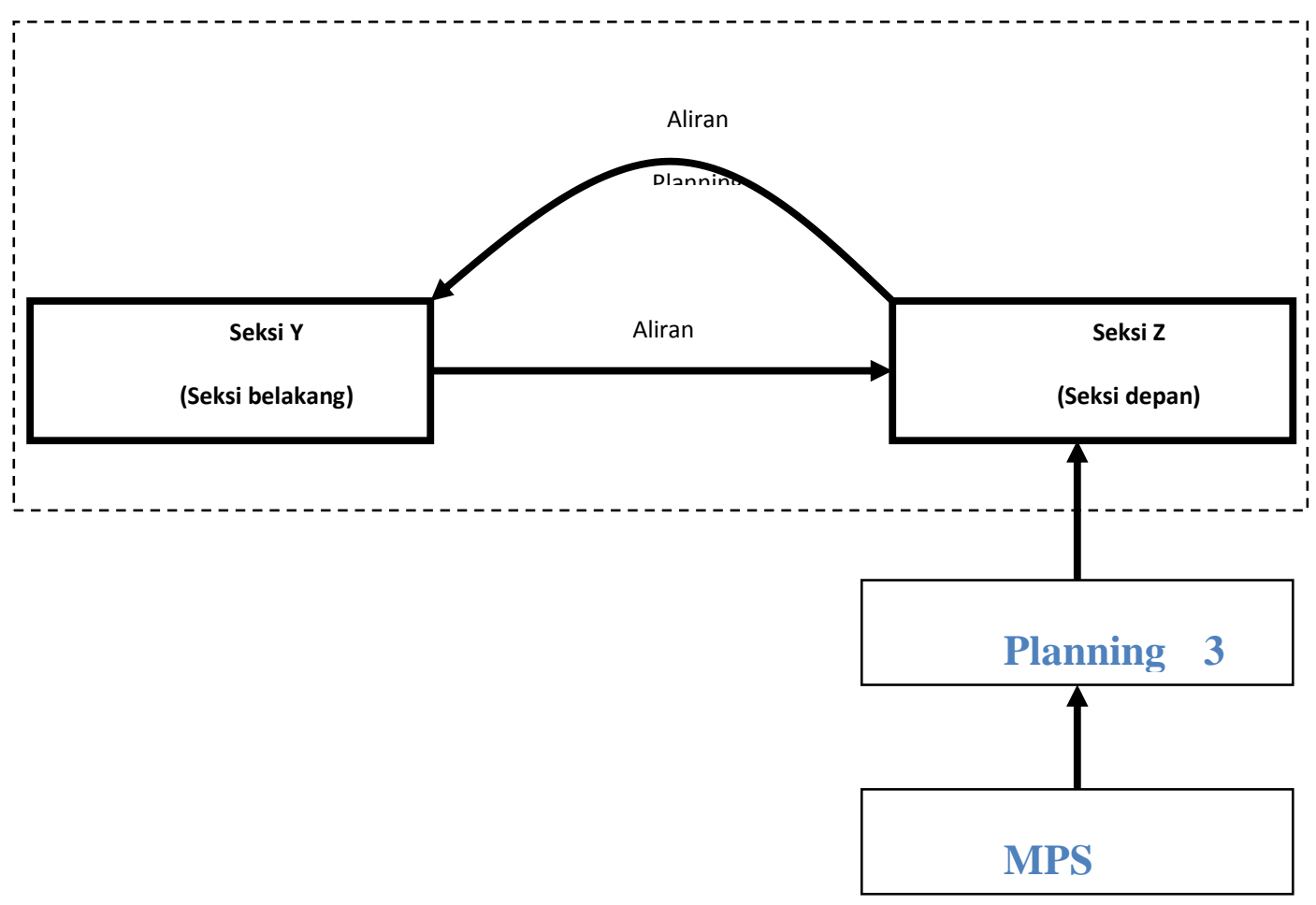

Sumber: PT Astra Honda Motor

Kebutuhan Finished Good $(F / G)$ per satuan waktu di masing-masing seksi produksi dibuat oleh Production Control sesuai dengan konsep yang berlaku di AHM (Konsep AHM Production System). Konsep AHM Production System dirancang sebagai sistem produksi yang sesuai dengan Just In Time dengan menggunakan Sistem Tarik. Kebutuhan $F / G$ seksi-seksi produksi dibuat berdasarkan Kebutuhan $F / G$ Seksi di depannya. Seksi yang paling depan di AHM adalah Seksi Assembling Unit. Planning di Seksi Assembling Unit merupakan Planning 3 Harian yang diterima oleh Production Control (PC) dari Production Planning. Planning 3 Harian itu sendiri diterjemahkan dari MPS bulan berjalan oleh Production Planning. Dengan demikian planning harian yang sehari-hari menjadi dasar bagi seksi-seksi produksi untuk bekerja, sangat terkontrol dan terencana sesuai dengan MPS.

\section{Kontrol Jalannya Produksi}

Di AHM Pusat Control jalannya produksi berada di PCR (Production Control Room) dimana Informasi sebagai modal dasar pengontrolan jalannya produksi andalan utama dalam sistem kontrol adalah manusia (man power). Distribution Operator, adalah ujung tombak dari sistem kontrol PC. Distribution Operator bertanggung jawab untuk menarik parts dari satu seksi ke seksi lain sesuai dengan kebutuhan seksi yang dikontrolnya. Setiap distribution operator memiliki area kontrol tersendiri, sehingga distribution operator merupakan orang yang pertama mengetahui segala bentuk informasi tentang seksi produksi yang berada di area kontrolnya. Dalam sistem kontrol di PC, Departemen Production Control sangat mengandalkan Distribution Operator sebagai orang yang bertanggung jawab untuk menarik barang sekaligus sebagai data collector. Distribution Operator menarik parts dari Warehouse ke Assy Unit berdasarkan trigger kereta kosong. Distribution operator dikoordinasikan oleh seorang parts controller. Seorang Parts Controller menerima informasi dari Distribution Operator untuk dikoordinasikan dengan Parts Controller lain bersama-sama dengan Staff Production Control. 
Gambar 4.3

PCR sebagai pusat informasi dan strategi produksi

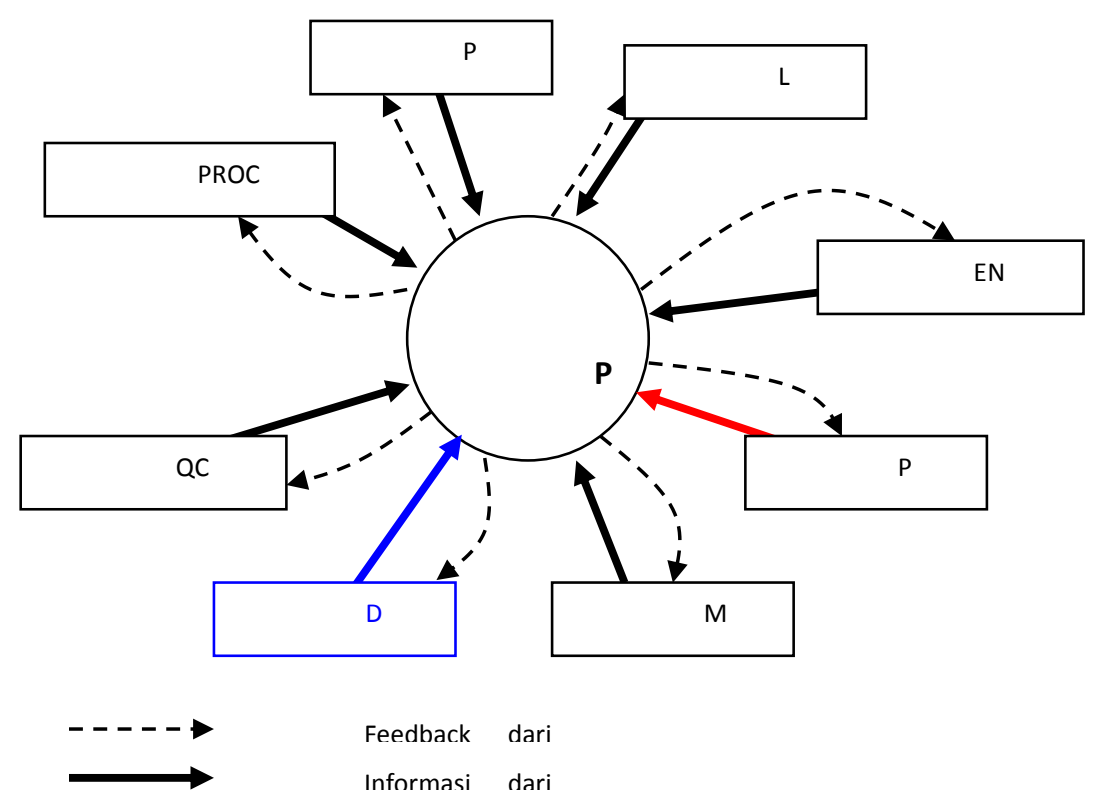

Sumber: PT Astra Honda Motor

Fungsi kontrol sangat berhubungan dengan pengambilan keputusan yang baik Dalam Ilmu Sistem Informasi dan Keputusan, kita ketahui bahwa untuk mengambil keputusan yang tepat, si pembuat keputusan harus mendapatkan informasi yang jelas dan akurat. Cepat atau lambatnya keputusan yang diambil sangat tergantung dari kecepatan dan keakuratan informasi yang diterima oleh si pembuat keputusan. Karena itu, informasi adalah modal dasar untuk melakukan kontrol terhadap produksi. Kesalahan informasi yang diterima bisa mengakibatkan kesalahan fatal dalam mengambil keputusan dan melakukan kontrol.

Untuk membuat keputusan yang tepat, $P C$ harus memperoleh informasi-informasi sebagai berikut:

1. Pencapaian produksi setiap periodenya

Untuk mengetahui kelancaran produksi, $P C$ dalam pengontrolannya melihat actual pencapaian produksi di tiap periodenya, dimana dalam 1 Shift kerja produksi terbagi menjadi 4 (empat) periode, dimana disetiap periode pihak engenering sudah menentukan kapasitas produksi unit disetiap periodenya. Dengan demikian $P C$ bisa melihat jalannya produksi apakah sesuai dengan harapan atau tidak, kalau tidak sesuai $P C$ hasus mengetahuai penyebabnya.

2. Informasi Part Kritis

Informasi parts kritis dapat diperoleh dari seksi warehouse. Form informasi parts kritis bisa diperoleh dengan mengakses file di komputer (soft copy) atau bisa juga diperoleh dengan meminta hard copy langsung dari warehouse. Setiap pagi, $P C$ harus mengetahui informasi Parts Kritis hari berjalan. Informasi parts kritis ini dibuat berdasarkan kondisi stock actual yang ada di warehouse. Seksi warehouse memiliki ketentuan tersendiri untuk menyatakan apakah suatu parts dikatakan kritis atau tidak.

Informasi parts kritis digunakan oleh $P C$ untuk menentukan apakah rencana produksi hari ke-n bisa berjalan dengan ideal. Dari informasi parts kritis bisa diketahui apakah parts dari subcontractor tidak akan mengganggu rencana produksi hari ke-n. Jika ada parts yang kritis di hari ke-n, maka $P C$ harus meminta schedule delivery parts yang kritis tersebut ke pihak Logistik dan melakukan adjustment terhadap rencana produksi. Tetapi kita juga harus melakukan koordinasi dengan Procurement untuk membahas masalah yang terjadi di subcontractor. Kita juga harus mengetahui langkah-langkah apa saja yang diambil untuk mengatasi masalah yang terjadi.

3. Masalah hari ini 
Masalah Hari Ini sangat berguna dalam menentukan urutan planning bahkan judgement apakah suatu lot mungkin untuk dikerjakan hari ini. Informasi tidak datang begitu saja, informasi harus ter-manage dengan baik.

Untuk mempermudah mendapat informasi yang cepat dan akurat, $P C$ harus menjalin kerjasama antar seksi dengan baik sehingga informasi yang baik dan jelas bisa diterima dengan cepat dan tepat. Berikut ini diuraikan beberapa contoh bentuk kerjasama $P C$ dengan seksi lain serta informasi apa saja yang dibutuhkan $P C$ dari seksi lain. Contoh ini hanya sebagian dari banyak bentuk kerjasama informasi yang dibutuhkan $P C$.

A. Seksi Produksi

Informasi yang dibutuhkan: Pencapaian Produksi Per periode, Jumlah $R / M$, WIP dan $F / G$, Masalah detail yang terjadi. Estimasi waktu pengatasan masalah, PICA, Warehouse, Informasi yang dibutuhkan, Parts Kritis, Kesiapan parts, PICA

B. Logistik

Informasi yang dibutuhkan: Schedule Delivery Parts Kritis, Stock Parts di Waho, PICA, Schedule Delivery REM Parts, Procurement, Informasi yang dibutuhkan, Stock Finish Good di subcont, Estimasi waktu penyesuaian delivery (jika ada masalah di SC), PICA

C. Process Engineering

Informasi yang dibutuhkan: Estimasi waktu down time, Schedule Maintenance, PICA

D. Facility Provider

Informasi yang dibutuhkan: Schedule Maintenance, Reliability Alat Pendukung Produksi, PICA

E. Shipping

Informasi yang dibutuhkan: Permintaan khusus , Stock FG di Shipping, PICA

$P C$ harus mampu menjadi pusat informasi dan harus mampu menjadi bagian (badan) yang menyusun strategi (taktik) yang tepat untuk menjamin produksi harian agar produksi dapat dicapai sesuai dengan MPS.

\section{Actual Produksi}

$P C$ yang setiap harinya bekerja sebagai pengontrol produksi tentunya memiliki tolok ukur keberhasilan kerjanya. Dalam pokok bahasan ini kita akan membahas apa dan bagaimana tolok ukur dari Production Control. Secara company, AHM dikatakan berhasil market share sepeda motor Honda di Indonesia meningkat. Direktorat manufaktur dikatakan berhasil jika direktorat tersebut mampu menghasilkan sepeda motor sesuai dengan permintaan market (pasar). Permintaan pasar setiap bulannya diterjemahkan ke dalam MPS yang harus dipenuhi. Tugas PPIC adalah menjamin bahwa produksi aktual tercapai sesuai dengan MPS. Sedangkan $P C$ adalah motor utama dari PPIC yang merencanakan dan mengendalian produksi harian. Berikut ini tolak ukur keberhasilan Production Control:

\section{Tercapainya Produksi yang Flat and Smooth Sesuai MPS}

Production Control bertanggung jawab terhadap Heijunka dengan menjamin bahwa produksi harian akan tercapai dengan smooth dan flat. Artinya Production Control harus menjamin bahwa setiap hari produksi yang direncanakan harus konsisten. Dalam Planning 5 Harian, terlihat jelas bahwa setiap motor dengan tipe dan warna yang sama berada pada urutan planning yang sama setiap harinya. Disamping itu, jumlah produksi harian juga dibuat flat (merata setiap hari). Setiap urutan lot harus dipertanggungjawabkan oleh Production Control, yang menjadi motor utama dalam pengendalian pencapaian produksi. Oleh karena itu salah satu kriteria performansi Production Control adalah tercapainya produksi harian sesuai dengan urutan planning lot-nya sehingga jumlah produksi harian menjadi rata.

\section{Produksi tanpa delay karena kesalahan delivery}

Production Control bertanggung jawab terhadap delivery parts antar seksi. Pergerakan parts antar seksi tidak boleh terganggu karena kesalahan Production Control, karena hal ini sangat merugikan perusahaan. Kesalahan kecil dapat mengakibatkan kerugian besar. Karena itu Production Control harus memperhatikan setiap detail pekerjaanya sehingga tidak terjadi kesalahan delivery yang mengakibatkan delay produksi. Dengan demikian jaminan akan kelancaran produksi tanpa adanya kesalahan menjadi salah satu kriteria performance $P C$.

3. Tidak ada Over Time Tambahan untuk mengejar produksi

Ramalan permintaan harian oleh konsumen dituangkan dalam MPS. Jumlah motor harian sesuai dengan jumlah yang ada di MPS secara harian harus disediakan karena diramalkan bahwa konsumen akan membeli motor dengan tingkat permintaan sebesar yang tertera dalam MPS setiap harinya. Minus 
produksi harian bisa menyebabkan lost of oppurtunity sales yang sangat merugikan perusahaan. Oleh karena itu jika terjadi minus produksi harian, Production Planning dan Production Control terpaksa merencanakan Over Time tambahan untuk mengejar akumulasi minus produksi yang sangat besar. Semakin banyak jumlah hari $O T$ tambahan untuk mengejar produksi, semakin buruk pula performansi perusahaan. Cerminan ini juga harus menjadi salah satu kriteria performansi Production Control. Production Control dan Production Planning harus memberi jaminan bahwa jumlah produksi bulanan harus dapat dicapai dengan jumlah hari kerja dan over time terencana seperti yang tertera dalam MPS. Production Control harus berusaha agar tidak ada Over Time tambahan dalam mencapai jumlah produksi sesuai yang tertera di MPS.

\section{Gambar 4 \\ Sistem Control PC Secara Umum}

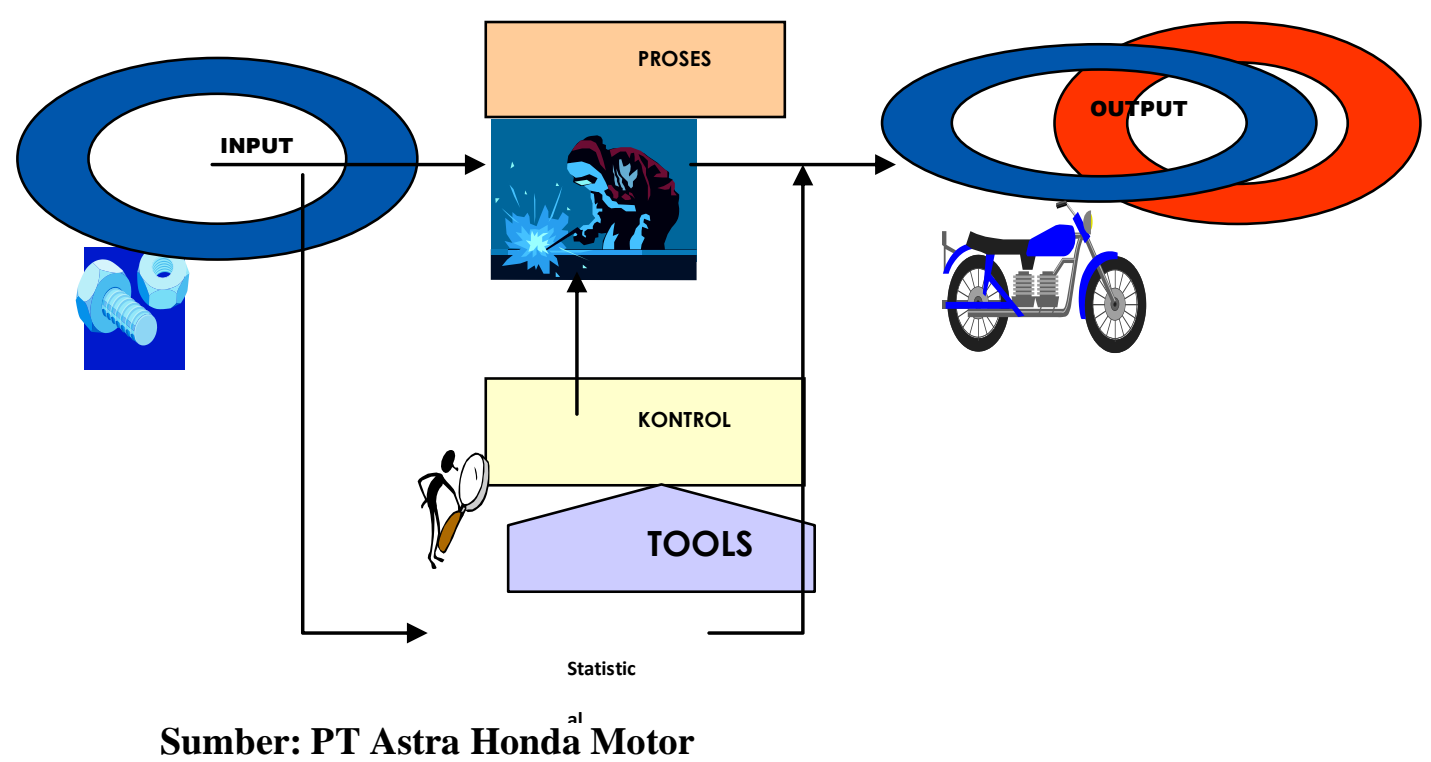

Tools Control digunakan oleh $P C$ sebagai alat bantu dalam melakukan kontrol produksi. Berikut ini adalah kumpulan tools control yang digunakan oleh PC : PC Control Board dari masing-masing Seksi, Planning 3 harian, Fix Planning, Negative list, Informasi part kritis

\section{Kendala yang terjadi}

1. Planning Produksi Apakah urutan planning pada hari berjalan (hari ke-n) boleh diubah ?

2. Pengontrolan produksi

Apakah Semi Finished Goods (SFG) Unit Motor diperbolehkan karena kekurangan parts?

3. Actual produksi

Apa yang sebaiknya dilakukan jika ada pihak yang berselisih pendapat tentang pembeban minus produksi di Assembling?

\section{Solusi untuk mengatasi Kendala yang terjadi}

1. Planning produksi

Sebaiknya tidak dilakukan perubahan planning di hari ke-n karena persiapan produksi dalam satu hari sudah fix di tiap-tiap bagian termasuk di subcontractor. Namun dalam kasus yang memaksa perubahan urutan planning diperbolehkan tetapi $P C$ harus meyakinkan bahwa dengan adanya perubahan urutan planning, seluruh parts untuk urutan planning yang baru telah tersedia.

2. Pengontrolan jalannya Produksi

Sebaiknya hal ini tidak dilakukan. Namun dalam keadaan penting genting $S F G$ diperbolehkan asalkan dapat diselesaikan pada hari itu juga. Untuk itu $P C$ harus meyakinkan kapan part yang kurang tersebut bisa dipenuhi.

3. Actual Produksi 
Semua pihak yang berselisih ditampung, meeting dengan seluruh pihak yang terkait dan undang juga bagian lain yang benar-benar mengerti dan terlibat dalam masalah ini dan diharapkan bisa menjadi penengah. Seluruh pihak yang hadir dalam meeting tersebut harus menjunjung tinggi hasil meeting karena hasil meeting tersebut sudah disepakati bersama.

\section{SIMPULAN}

System control yang dijalankan pada PT Astra Honda Motor sudah berjalan dengan baik, hal tersebut dapat disimpulkan sebagai berikut:

1. Planning Produksi

Planning produksi adalah perencanaan produksi unit motor dengan kapasitas untuk 1 (satu) tahun, bulanan, mingguan, maupun harian untuk memenuhi keinginan konsumen yang dalam hal ini diwakili oleh pihak marketing.

2. Kontrol Jalannya Produksi

Di AHM pusat informasi produksi berada di $P C R$ yang mana informasi sebagai modal dasar pengontrolan jalannya produksi andalah manusia (man power). Distribution Operator, adalah ujung tombak dari sistem kontrol PC. Distribution Operator bertanggung jawab untuk menarik parts dari satu seksi ke seksi lain sesuai dengan kebutuhan seksi yang dikontrolnya.

3. Actual Produksi

$P C$ yang setiap harinya bekerja sebagai pengontrol produksi tentunya memiliki tolok ukur keberhasilan kerjanya, yang mana tolak ukur keberhasilan $P C$ adalah produksi berjalan sesuai $M P S$, produksi tanpa delay yang disebabkan kesalahan delivery part, dan tidak ada over time tambahan untuk menejar produksi.

Namun dari hal-hal yang sudah disimpulkan penulis di atas terdapat kendala yang harus diselesaikan dalam menjalankan Prosedur Production Control yaitu:

a. Planning Produksi

Apakah urutan planning pada hari berjalan (hari ke-n) boleh diubah

b. Kontrol Produksi

Apakah Semi Finished Goods (SFG) Unit Motor diperbolehkan karena kekurangan parts

c. Actual Produksi

Apa yang sebaiknya dilakukan jika ada pihak yang berselisih pendapat tentang pembeban minus produksi di Assembling

\section{SARAN}

Kerja sama tim antara seksi Production Control dan seksi-seksi lainnya sangatlah penting dan menentukan apakah produksi akan sesuai dengan perencanaan.

Adapun saran-saran yang dapat diberikan sebagai berikut:

1. Apabila diharuskan ada perubahan urutan planning yang disebabkan part delay atau kualitas dari Subcontractor, maka pihak AHM harus memberi sangsi keras agar tidak terulang kembali.

2. Untuk antisipasi part reject yang masuk ke bagian produksi pihak Quality Incoming harus menjamin bahwa part yang akan didelivery $P C$ kondisi part bagus.

3. Sebaiknya $P C R$ harus lebih tegas lagi dalam pengambilan keputusan. Harapannya dalam meeting tidak berlarut-larut dalam penentuan pihak mana yang akan masuk dalam Negative List.

4. Penambahan SDM di seksi Quality Incoming.

\section{DAFTAR PUSTAKA}

Fahmi, Irham. Manajemen Produksi dan Operasi. Bandung: Alfabeta, 2014.

Murdifin, Haming \& Nurnajamuddin Mahfud. Manajemen Produksi Modern Operasi ManufakturIng dan Jasa Buku 2 (dua). Jakarta: Bumi Aksara, 2012.

Purnamasari, Evita, P. Panduan Menyusun SOP. Yogyakarta: Kobis, 2015.

Santoso, Joko, Dwi. Lebih Memahami S.O.P (Standard Operation Procedure). Surabaya: Kata Pena. 2014.

Sofyan, Dian, Khairani. Perencanaan dan Pengendalian Produksi. Yogyakarta: Graha Ilm,. 2013.

Suemohadiwidjojo, Arini T. Mudah Menyusun SOP. Jakarta: Penebar Plus, 2014. 
Umam, Khaerul. Manajemen Perkantoran (Referensi untuk Para Akademisi dan Praktisi). Bandung: CV Pustaka Setia, 2014.

Kamus:

Virgirama Reyhan \& Abdar Sulthon. Kamus Lengkap Bahasa Indonesia. Jakarta: Garda Media, 2013 